\title{
Methodology to develop land capability maps using geo-information systems (GIS)
}

\author{
Mladen Jurišić*, Ivan Plaščak and Tomislav Jurić \\ Department of Agrotechnic and Precision Agriculture, Faculty of Agriculture, University of J. J. Strossmayer in Osijek, \\ Osijek, Croatia.
}

Accepted 8 October, 2012

\begin{abstract}
The purpose of this research was to determine the methodology of land capability evaluation with regard to an array of objective limiting factors when growing, for example, perennial crops. The methodology of relief parameterization was used in the method for calculating geomorphological parameters, and pedometric mapping methods were used to calculate pedological variables. Inventory of the actual condition of land cover was made based on sketches and maps that were gathered during field research. These sketches were then geo-referenced and overlapped with LANDSAT satellite images to determine the actual situation. The best locations for a particular type of perennial plantation were selected by using logic and spatial queries. Best locations, in this example for vineyards, were identified as an area overlap, areas with, according to the spatial plan, either valuable, especially valuable or other arable soils, southern relief exposition with the total annual incident light $>1,208 \mathrm{KWh} / \mathrm{m}^{2}$, and the location where the relief slope is between 2 and $12 \%$ or where elevation exceeds $110 \mathrm{~m}$ and soil acidity does not exceed $5.6 \mathrm{pH}$. The query resulted in a simple map. The map shows areas which are either suitable for viticulture " 1 " or not suitable for viticulture " 0 ". Analysis of the results obtained from the example revealed the methodology for development of thematic maps in geo-information systems (GIS) environment, a total of 17, 782 ha in the Osijek-Baranja County, Republic of Croatia, area is suitable for viticulture.
\end{abstract}

Key words: Geo-information systems (GIS), thematic maps, resource management, spatial plan, land capability mapping, viticulture, European union (EU) pre-accession funds, Croatia.

\section{INTRODUCTION}

To improve efficiency and competitiveness of an industry, that is, efficiency of resource management in a country, governments of these countries, especially the European Union member states, adopt the so-called operative programmes to stimulate loans to such industries. The goal of such programmes is to increase efficiency of different aspects of management. For example, it is of great importance for the Republic of Croatia to make an inventory of resources, that is, to improve their use and efficiency. Through various projects supported by the
European Union and its programmes related to the use of pre-accession funds, the Croatian government stimulates an increasing number of small and large entrepreneurs, even family farms, to increase their plantations and to become serious producers with a higher share in the market economy. To allocate funds from such sources in the best possible way, the following is required: to educate economic operators, land owners and company owners, especially those related to resource management, on the possibilities and to carefully choose 


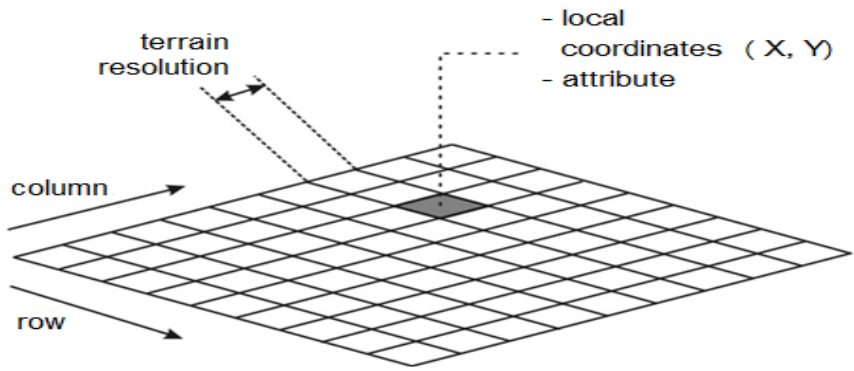

Figure 1. Raster based GIS: each thematic layer consists of the smallest unit of pixel or grid square which is determined by the field resolution.

among the received loan applications. Among other, it is necessary to have a good knowledge of production potentials of a particular location, land owned by the requesting party, so that as much funds as possible is invested into areas with the highest production potential related to targeted production.

Accelerated development of geo-information technologies has taken place also in our country, application in various fields, especially in natural resource management. Inventory of large areas can be made very quickly either by using satellite images or by positioning by means of global positioning system device or digital aero-photogrammetry (Jurišić et al., 1999, 2005; Husnjak and Bogunović, 2002).

Thematic maps of different purposes in Croatian agriculture have already been in the process of making, although not to a sufficient extent. Among organized systems of implemented geo-information technologies, a digital land registry, the Land Parcel Information System (LPIS), which is part of the Integrated Administration and Control System (IACS), should be mentioned in such cases. For example, Croatian Institute of Viticulture and Enology has started to develop a detailed Vineyard Register, which should provide a general statistical overview of all vineyard areas on a single production area as well as potential areas.

Issues discussed in this study include what methodology should be used in the process and what funds and human resources are required. These issues are addressed in this paper. The methodology of carrying out the land capability evaluation while considering an array of limiting factors of production for strategic types of perennial plantations is presented on the example of Osijek-Baranja County, Republic of Croatia.

\section{METHODOLOGY}

Geo-information system (GIS) has been in used in Croatia for the purpose of planning at the regional level for some ten years. The methodology used in this example and for the purpose of planning in the field of management of resource use is specific in the part that parameters for land evaluation are clearly and precisely defined (geomorphological, pedological and actual condition of land cover). The methodology of parameterization of relief is used for calculation of geomorphological parameters (Hengl et al., 2003), and pedometric mapping methods are used for calculation of pedological variables (Hengl, 2003). Inventory of the actual condition of land cover is made by using sketches and plans obtained during field data gathering. These sketches are then georeferenced and overlapped with LANDSAT satellite images to determine the actual situation. The methodology of raster GIS modelling was used throughout the study, which means that the basic decision making unit was pixel or cell grid square (Figure 1). The methodology of preparing thematic layers follows.

\section{Field data collection}

To evaluate (locate) the current situation in the field in the best possible way, the field was recorded during visit to the main local farms and their owners. Shorter surveys can be carried out in the process with farm owners. In addition to obtaining important technical data, this also provides an insight into the main issues in production. Also, each farm owner is required to submit a map showing the current situation and the location. These mostly include sketches or old plans that were either copied by hand or photocopied and thus diminished from the original cadastral maps. Maps very often include a legend on the field boundaries showing the types of crops grown, and each field has its own identification number.

\section{Preparation of the thematic GIS layers}

In the process of preparing GIS layers, several raster resolutions are used:

(1) Basic resolution for calculation of suitability, $100 \mathrm{~m}$;

(2) LANDSAT image at 30 and $15 \mathrm{~m}$ resolution;

(3) A detailed topographic map 1:100 K, also at $15 \mathrm{~m}$ resolution.

Boundaries of the area are set to $X_{\min }=6490027 ; Y_{\min }=5005476$; $X_{\max }=6587527 ; Y_{\max }=5088076$ (Gauss-Krueger system, zone 6), which means that the total area is $97 \times 83 \mathrm{~km}$. Panchromatic image is at $15 \mathrm{~m}$ resolution (5508 $\times 6501$ pixels). According to this methodology, the following thematic layers are made.

\section{Topographic map 1:100K (topo100K)}

Sheets of $1: 100 \mathrm{~K}$ topographic map, scanned and geo-referenced to the coordinate system (zone 6), are used as GIS foundation. In our example, total of 19 sheets of topographic map of the Republic of Croatia were geo-referenced and joined together.

\section{Scanned sketches (fields)}

They present the current condition of perennial plantations. In our example, sketches and maps of four main local farms were gathered for the purpose of this study. After geo-referencing, all scanned sketches were transferred into the vector format (Figures 2 and 3).

Digital relief model and relief parameters (DMR, slope, and light)

Digital relief model, DMR is produced based on the combination of the shuttle radar topography mission digital relief model, (SRTM DMR) (NASA, 2005a) and DMR which was developed based on digitalized contour lines from $1: 100 \mathrm{~K}$ topographic maps. In this 


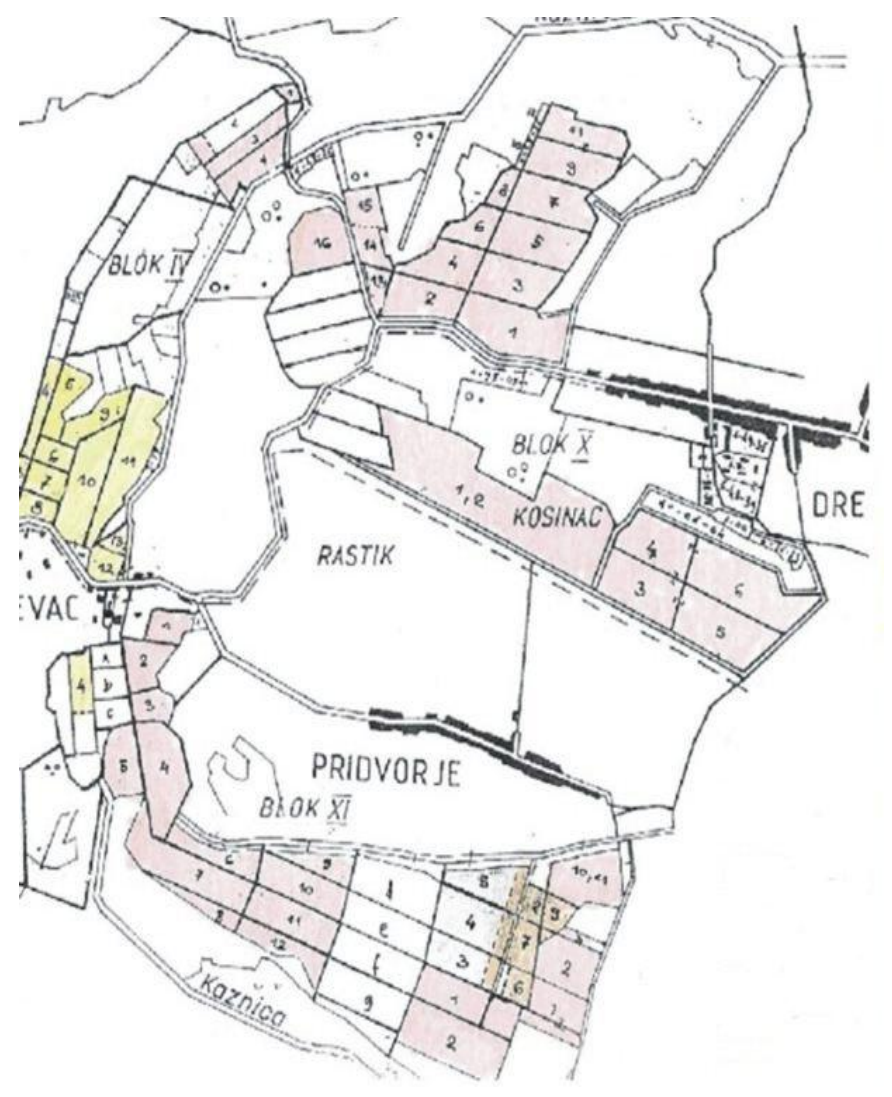

Figure 2. Importing and assessment of old sketches and maps into GIS, an example of an old plan.

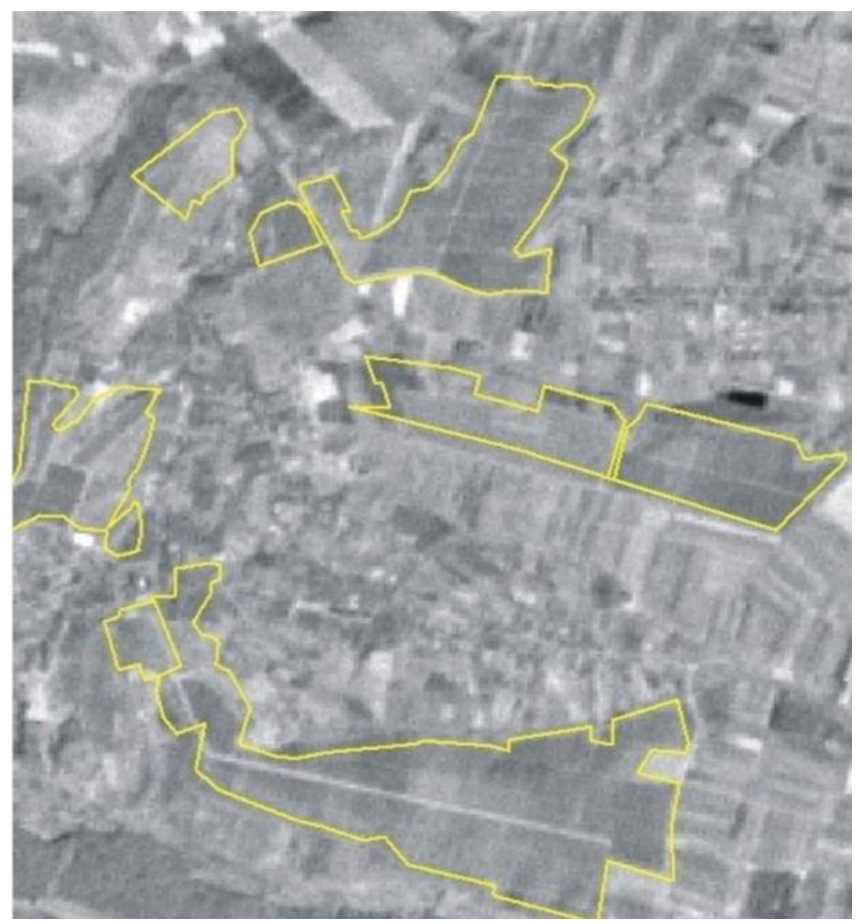

Figure 3. Importing and assessment of old sketches and maps into GIS, map of plots can be represented in a satellite image after geo-referencing. case, the DMR based on topographic maps has greater absolute accuracy, while SRTM DMR shows greater local detail (changes in the mezzo relief). SRTM DMR was not used in areas with rich vegetation, because SRTM DMR usually shows the surface of such objects, and not the real elevation of the terrain. Two geomorphological factors were calculated based on DMR: slope (\%) and the total annual amount of incident light. The slope was calculated by means of the Integrated Land and Water Information System (ILWIS) GIS software (The $52^{\circ}$ North, 2007), and incident light $\left(\mathrm{KWh} / \mathrm{m}^{2}\right)$ by the System for Automated Geo-scientific Analyses (SAGA) GIS software (Olaya, 2004). Even these two parameters (slope and exposition) are sufficiently important for finding the best locations for some production (viticulture) (Figure 4).

\section{Planned land use}

The planned land use was based on the spatial plan developed by the Institute for Spatial Planning of Osijek-Baranja County (Institute for Spatial Planning of Osijek-Baranja County, 2002). This is a 1:100K scale map which was scanned, geo-referenced in ILWIS and then digitized and polygonized. The total area statistics was calculated after that, with special emphasis on agricultural land in the Osijek-Baranja County. The map of the planned land use is important to limit selection of the best locations for fruit/vine growing on the locations where valuable and especially valuable soils are found.

\section{Pedological parameters (soil type, $\mathrm{pH}$, and carbon)}

In addition to soil type (deep, fertile, gravel or dry), when selecting the soil in the process of vineyard planting, it is of utmost importance to know the content of lime in the land envisaged for planting, for the depths $(0$ to 30 and 30 to $60 \mathrm{~cm}$ ). Maps of soil acidity and carbonate content were made by interpolation of a limited number of pedological profiles. The database of soil types in Croatia was used (Martinović and Vranković, 1997); the total of 124 profiles from this database can be found in the County area. The data were interpolated so that a map of soil types was made in the beginning (Alluvial, Chernozems, District Brown Soil, Eutric Brown Soil, Colluvial Soil, Loess Soil, Meadow Soil, Wetland Gley Soil, Pseudo-gleyed Soil, Rendzina, Wetland Black Soil, and Semi-gley) by classifying geomorphological parameters, and then the mean value of pedological parameter was calculated for each soil type like $\mathrm{pH}$ and carbonates.

\section{Satellite image (Panchromatic)}

LANDSAT panchromatic satellite image was used at $15 \mathrm{~m}$ resolution. The image was made in September 1999. LANDSAT images $(185 \times 185 \mathrm{~km}$ scene) can be ordered and downloaded online via NASA server (NASA, 2005a). Such an image is especially suitable for this kind of projects, because it can be compared to the photo mosaic, which would be more expensive. Boundaries between the plots of agricultural land are clearly visible in the image as well as larger furrows within vineyards. To provide easier recognizing of orchards and vineyards, aero or Ikonos images should be used in future (Figure 5).

Map importing, geo-referencing and integration are carried out as follows:

(1) Maps are scanned at 150 dots per inch (DPI) resolution and more;

(2) Scanned maps are imported into a GIS software ILWIS and georeferenced to the local coordinate system, 1:100K scale (Figure 6); 


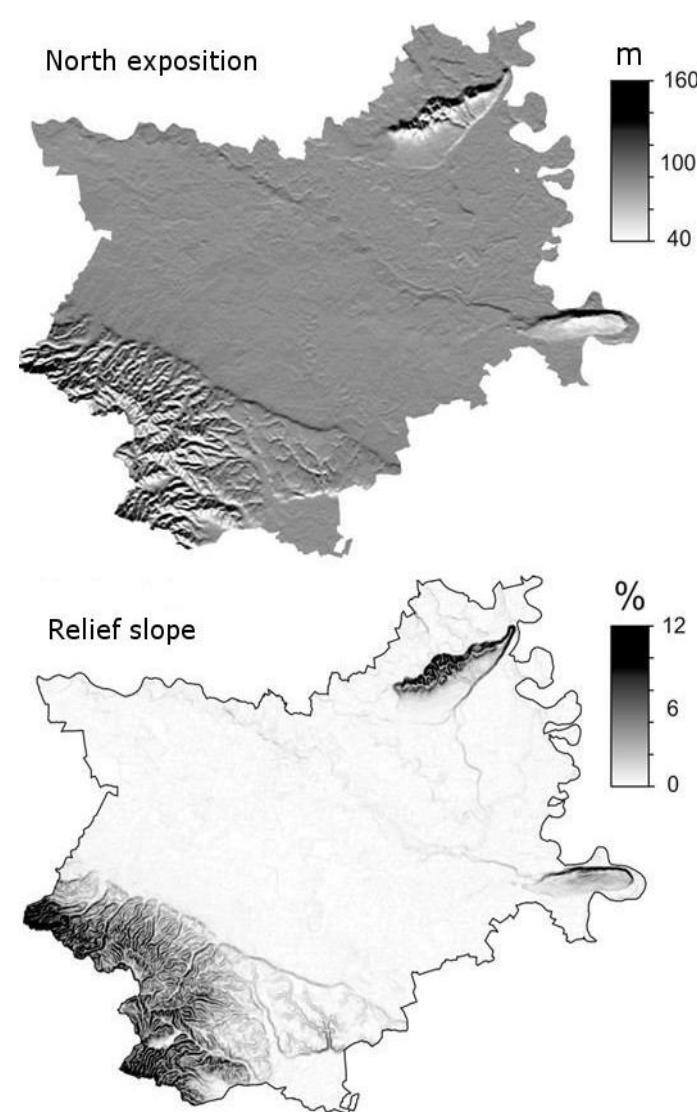

Figure 4. Geomorphological parameters calculated on the basis of digital model of the relief of OsijekBaranja County, Croatia.

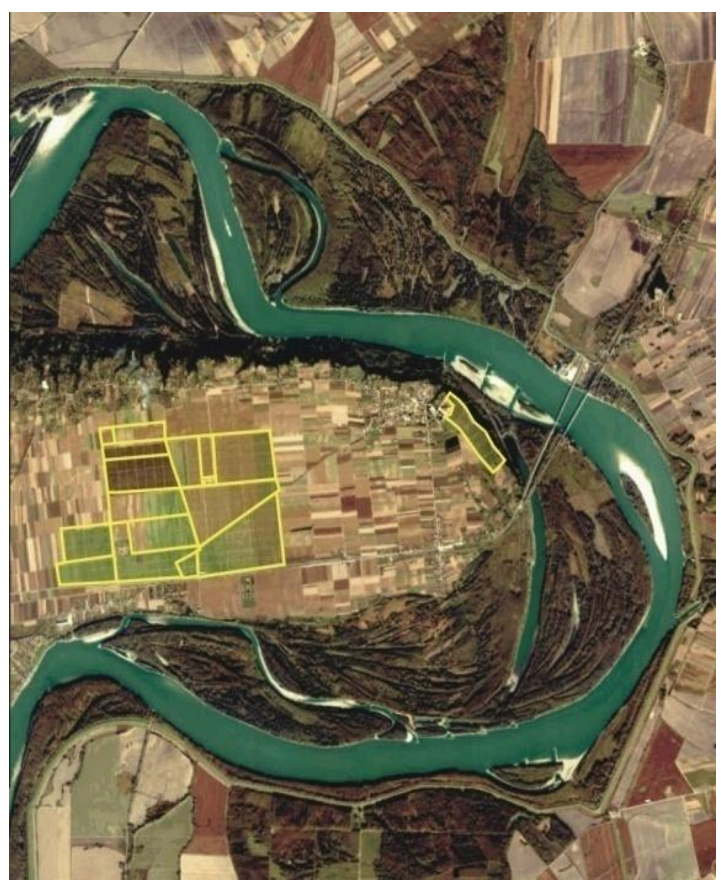

Figure 5. An example of lkonos image, $1 \mathrm{~m}$ resolution, which can be used to make fast inventory of vineyards (Erdut vineyards outlined in yellow).

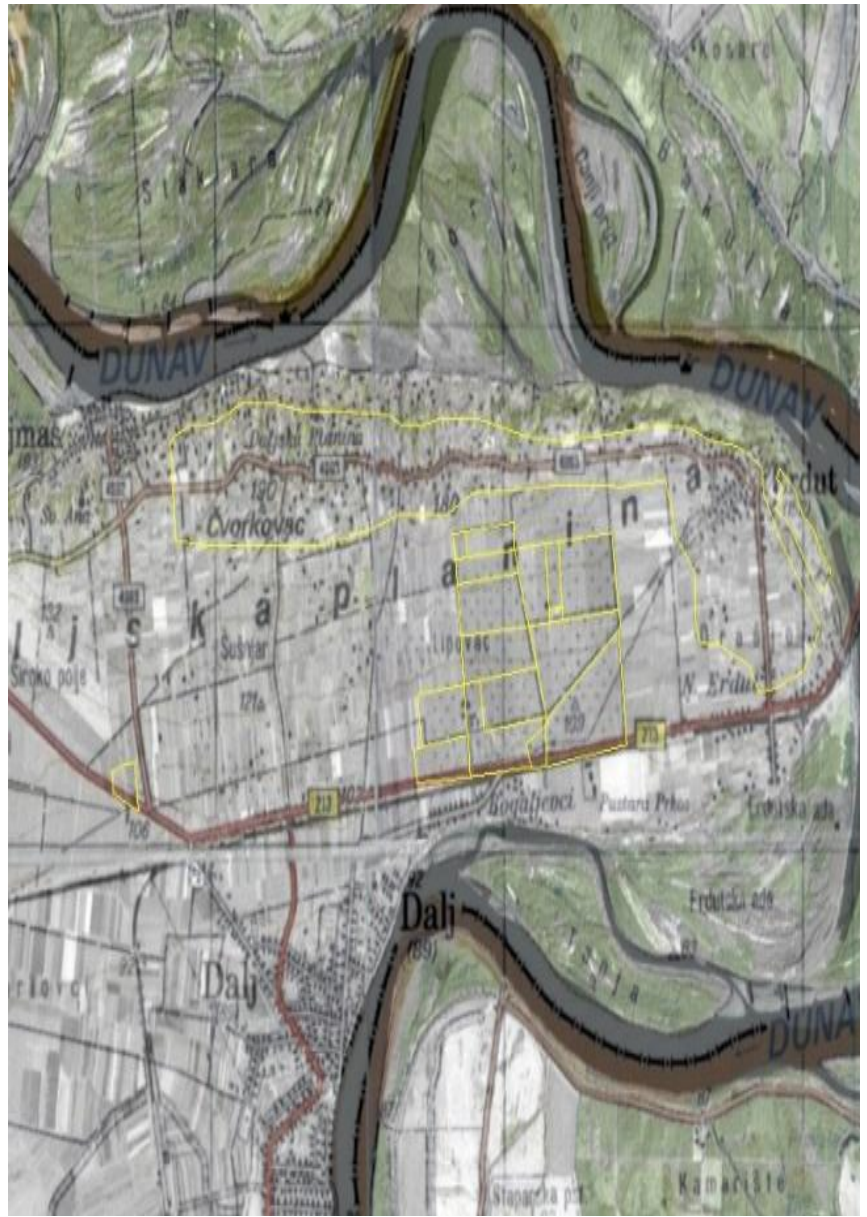

Figure 6. Integration of ILWIS and GIS layers using Erdut Hill as an example, vineyards owned by the wine-making company Erdutski vinogradi.

(3) Parts of maps are joined and modified according to the desired basic resolution and detail level;

(4) Different thematic layers, such as slope maps, are used for simple and more complex calculations (for example, annual amount of direct solar radiation);

(5) Ultimately calculated thematic maps are used for decision making by using the so-called spatial queries; these queries are carried out in ILWIS directly.

\section{Selection of best locations}

Selection of the best location for a particular type of perennial plantation is carried out by using logical and spatial queries. Locations for vineyards are defined as overlapping areas between:

(1) according to the spatial plan, either valuable or especially valuable soils and other arable land can be found; (2) southern exposition of relief with the total annual amount of light incidence $>$ $1208 \mathrm{KWh} / \mathrm{m}^{2}$; (3) the slope is not higher than $12 \%$ and lower than $2 \%$, and (4) the elevation is at least $110 \mathrm{~m}$ above sea level and soil acidity does not exceed $5.6 \mathrm{pH}$ units.

This means that locations will be found that satisfy several important criteria in the same area (good exposition and good slope, good elevation, etc). Such spatial enquiry can be expressed by means of the following ILWIS commands (so-called ILWIS syntax): 
Suitable_Vineyards $\{$ dom $=$ Bool $\}=$ iff (purpose="Especially Valuble Soil ") or (purpose="Valuble Soil ") or (purpose="Other Arable Soils ") and (light>1220) and (slope<12) and $(\mathrm{DMR}>110)$ and (soil_pH>5.6), 1, 0 .

This is the so-called "Boolean" operation, because the result of the query will be a simple map showing areas which are either suitable for viticulture " 1 " or not suitable for viticulture " 0 ". If the user wishes to increase the selection criteria, he/she can simply change any of the parameters directly in ILWIS command, for example, slope $<10 \%$ instead of $<12 \%$. Of course, the more strict criteria will result in smaller area of suitable locations.

Alternative to this Boolean procedure would be the use of limitations scores. In that case every parameter, limiting agroenvironmental effect, is translated into a limitation score according to a mathematical or empirical formula. Use of limitation (negative) scores in this case is considerably more complex, because relations among the negative scores and limiting parameters are unknown. In addition, the number of agro-environmental factors can be pretty large, which means considerably larger calculations in GIS.

\section{RESULTS AND DISCUSSION}

A map of the best locations for vineyards was developed based on a Boolean approach. This map is the ultimate result of this work (Figure 7). According to an estimate, around 17,782 ha in the county are suitable for viticulture. When compared with the actual use $(1,612 \mathrm{ha})$, the current utilization rate of resources in viticulture is around $10 \%$.

Locations, owned by Vinski Podrumi Belje Company, that are unsuitable for vineyards are all locations situated on the sea level below $120 \mathrm{~m}$, on the localities oriented toward north, north-eastern and eastern sites, unprotected against penetration of cold air; in area owned by Erdutski Vinogradi Company, all locations where water is stagnant and frost can occur (depressions, furrows, and micro-coves). Areas unsuitable for vine grape growing can also be found in areas owned by Feravino Company and Đakovačka Vina Company, all locations where slopes exceed $12 \%$ and soil is acid or very acid, $\mathrm{pH}<5.0$. In terms of slope and suitability for use of mechanization, only the area around have issues due to the earlier described micro-relief.

These scales can be used to find the best locations for planting new vineyards. However, the areas that are not coloured green in the Figure 7 show areas which could not be recommended as suitable for viticulture, that is, loans or incentives for them should not be provided by the county or government. Analysis and processing of climate and edaphic parameters points to a very favourable climate and land conditions for vineyards as well as existence of great resources and the possibility for intensifying as well as rationalization of future production. A conclusion can be made as the end result of this research that utilization rate of natural resources in viticulture is around $10 \%$ and that the most suitable locations for planting vineyards is the area of Erdut Hill and numerous locations between Đakovačka Vina Company and Feravino Company owned areas (Figure 8).

\section{Conclusion}

This scientific research is mostly of methodological character, that is, the goal is to bring the methodology of detailed spatial planning in GIS closer to the employees of the County Department for Agriculture and Forestry and other stakeholders. Unlike the methodology used by the Croatian Institute for Viticulture and Enology, this research was conducted in the GIS. Relief data and satellite images were also used to verify the situation. Integration and combination of ortho-photo images and vineyard register with relief and satellite images would provide even better results than the results presented in this paper. If aero images are too expensive solution for development of the county GIS, use of Ikonos images should also be considered (Table 1).

There are large numbers of potential users and applications which are based on updated geoinformation, that is, digital purpose maps. Decisions about the land use and its change in Croatia are still not made based on objective queries and criteria. Unfortunately, in our country, there are no updated and detailed maps of areas which would show the actual situation in land use, the real potential of natural resources (soil, water, and relief). All of the basic foundations of geodesy as the cadastre, aero photos and topographic maps, have also not been transformed into digital form and made available to these services. Tools for relatively urgent and objective monitoring of changes in land use (satellite images), changes of the boundaries between agricultural units (aero-photos), positioning (GPS) and general condition of natural and human resources are not used.

Problems with the cadastre, land restitution, allocation and undefined ownership structure of land in the state ownership are a limiting factor in the process of determining the status and future purpose of these areas. Raising new perennial plantations and stimulation of potential producers (legal and physical entities) requires an extremely fast engagement at both national and county level in an extremely short period of time (a few years, European Union accession).

In this example of development of a thematic map showing land suitability for growth of grape vine, the main microclimate factors limiting successfulness of production in the entire county area are: local frost areas; slope over $15 \%$; and insufficient carbonate content in the soil, that is excessive soil acidity. Ideal soil for grape vine production is mildly sloped (2 to $12 \%$ ), of southern, south-western and western exposition, calcareous or mildly calcareous, with humus content around $3 \%$, and of light texture (powdery/sandy loam). Further steps shall include development of the full multidisciplinary Geographic and Cadastral information System (GIZIS) of regions with agricultural production, and education of all key users, primarily employees of the County Development Department on how to use these tools. 


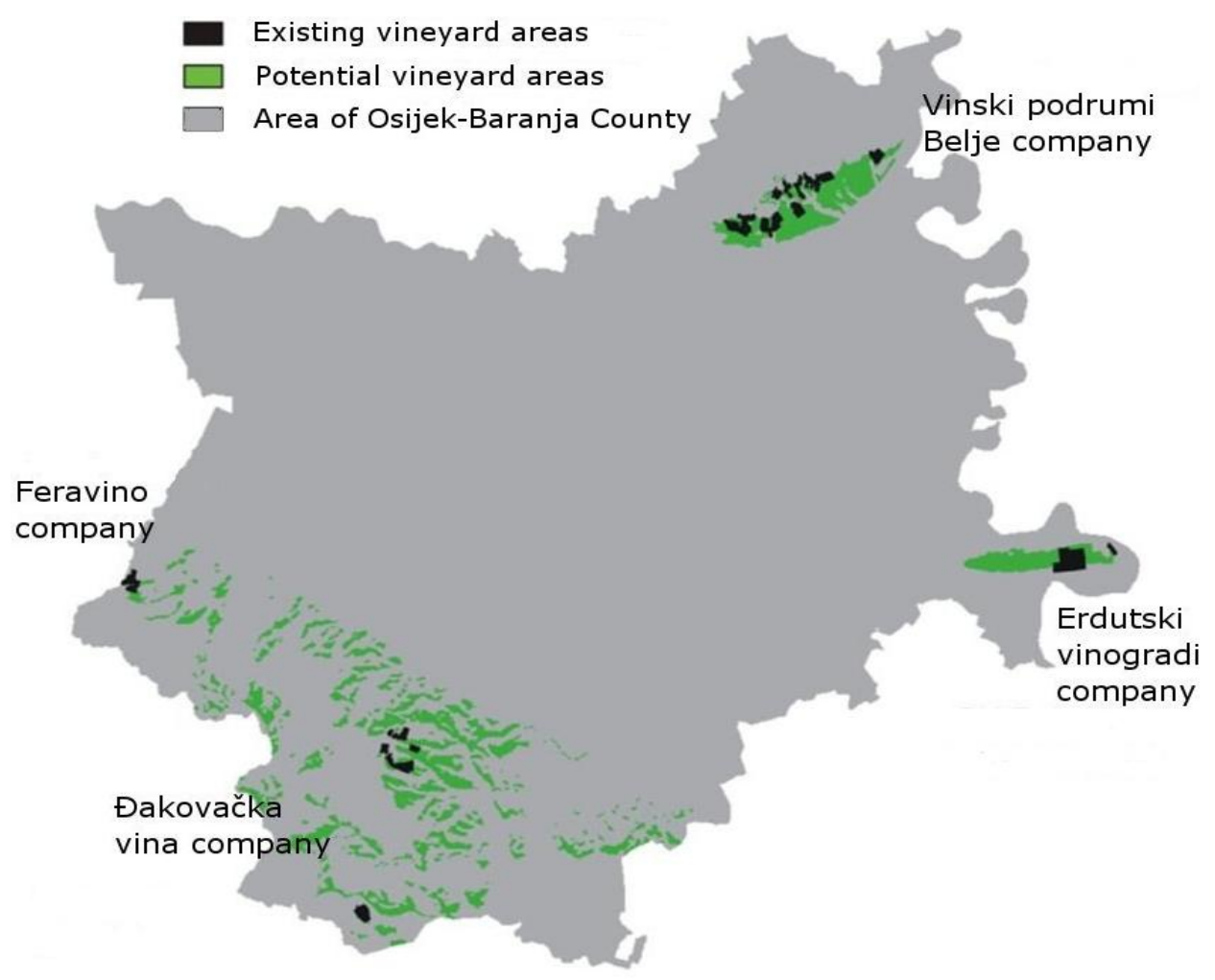

Figure 7. The existing and potential areas under vineyards in 2004.

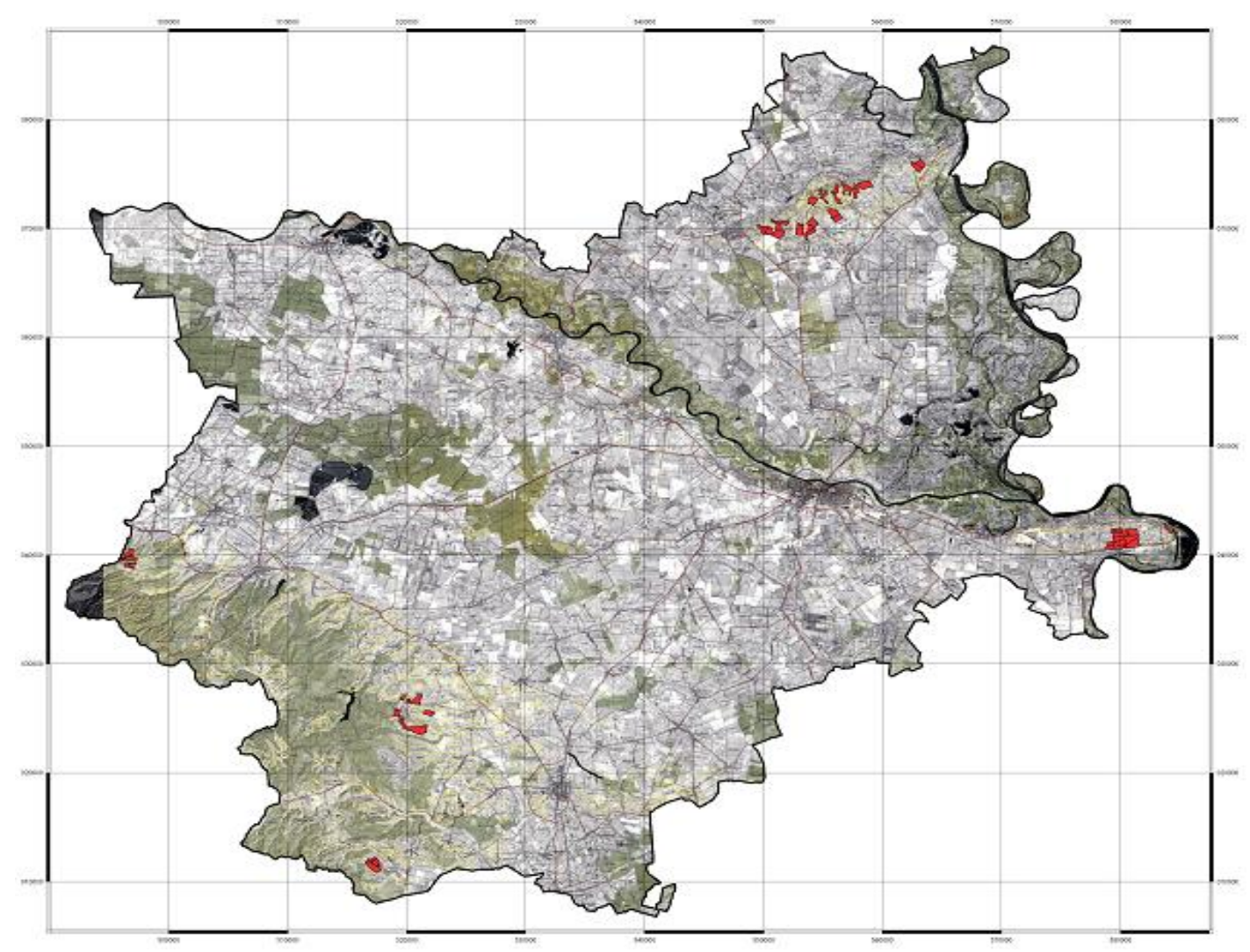

Figure 8. Land capability map for viticulture (areas in red, the current use) in Osijek-Baranja County. 
Table 1. List of GIS layers used in the development of the study.

\begin{tabular}{|c|c|c|c|}
\hline GIS layer & Unit & Description and characteristics & Application \\
\hline Topo100K & - & $\begin{array}{l}\text { Scanned and geo-referenced topographic map } \\
\text { 1:100K. Raster map in real colours. Map size, } 5508 \\
\times 6501 \text { pixel }\end{array}$ & $\begin{array}{l}\text { Basic foundation for preparation of all } \\
\text { other GIS layers }\end{array}$ \\
\hline Field & - & $\begin{array}{l}\text { Scanned, geo-referenced and vectorized plot } \\
\text { boundaries. Vector map; total around } 200 \\
\text { tables/plots }\end{array}$ & $\begin{array}{l}\text { Showing the current situation and } \\
\text { locations of perennial plantations (PP) in } \\
\text { the county area }\end{array}$ \\
\hline DMR & $\mathrm{m}$ & $\begin{array}{l}\text { Digital relief model is a raster map showing the field } \\
\text { elevation for each point in the space. Map size, } 827 \\
\times 976 \text { pixels }\end{array}$ & $\begin{array}{l}\text { It can be used for calculation of } \\
\text { geomorphological and hydrological } \\
\text { parameters, but also for 3D } \\
\text { representations }\end{array}$ \\
\hline Slope & $\%$ & $\begin{array}{l}\text { Raster map developed on the basis of DMR, } \\
\text { showing field inclination. Also in this case } 100 \mathrm{~m} \text { grid } \\
\text { was used }\end{array}$ & $\begin{array}{l}\text { A very important agro-environmental } \\
\text { parameter because it is related to } \\
\text { agricultural production ( }>12 \% \text { is not } \\
\text { suitable for mechanization application). }\end{array}$ \\
\hline Light & $\mathrm{KWh} / \mathrm{m}^{2}$ & $\begin{array}{l}\text { Raster map calculated on DMR basis and } \\
\text { knowledge of the solar radiation model }\end{array}$ & $\begin{array}{l}\text { It can be used to locate the areas suitable } \\
\text { for vineyards. Southern exposition shows } \\
\text { the highest values. }\end{array}$ \\
\hline Land use & Class & $\begin{array}{l}\text { Polygon map showing land purpose classes } \\
\text { according to the spatial plan }\end{array}$ & $\begin{array}{l}\text { Spatial planning of agricultural production } \\
\text { should be limited to the locations where } \\
\text { agricultural land is found }\end{array}$ \\
\hline Soil type & Class & $\begin{array}{l}\text { Raster map showing soil types from alluvial to } \\
\text { chernozem and renzina soils in mountains }\end{array}$ & $\begin{array}{l}\text { Based on the soil type, a conclusion on } \\
\text { other soil characteristics can easily be } \\
\text { made }\end{array}$ \\
\hline Soil pH & $0-15$ & $\begin{array}{l}\text { Raster map produced by interpolation of observed } \\
\text { values. In this case average was made according to } \\
\text { soil type map }\end{array}$ & $\begin{array}{l}\text { Acidity is usually the key limiting factor for } \\
\text { agricultural production }\end{array}$ \\
\hline Soil carbonates & $\%$ & $\begin{array}{l}\text { Raster map produced by interpolation of observed } \\
\text { values. In this case average was made according to } \\
\text { soil type map }\end{array}$ & $\begin{array}{l}\text { Vineyards require more carbonate soils. } \\
\text { Acid soils may result in under- } \\
\text { performance }\end{array}$ \\
\hline $\begin{array}{l}\text { Panchromatic } \\
\text { imagery }\end{array}$ & $0-256$ & $\begin{array}{l}\text { Raster image, the smallest detail } 15 \mathrm{~m} \text {. Map size, } \\
5508 \times 6501 \text { pixels }\end{array}$ & $\begin{array}{l}\text { Useful for recognizing the boundaries } \\
\text { between agricultural land plots }\end{array}$ \\
\hline
\end{tabular}

\section{REFERENCES}

Hengl T (2003). Pedometric mapping: bridging the gaps between conventional and pedometric approaches. Ph D thesis, University of Wageningen, Enschede. p. 214.

Hengl T, Gruber S, Shrestha DP (2003). Digital Terrain Analysis in ILWIS. Lecture notes and users' guide. International Institute for GeoInformation Science \& Earth Observation (ITC), Enschede. Netherlands. p. 45.

Husnjak S, Bogunović M (2002). Application of GIS technology in land management in Croatia. Proceedings of paper on CD-ROM of 17th World Congress of Soil Science. 14-21 August. Bangkok. Thailand. Papers on CD. No 340/1-10.

Institute for Spatial Planning of Osijek-Baranja County (2002). Jurišić M, Hengl T, Duvnjak V, Martinić I (1999). Agro-ecological and land information system. Strojarstvo 41(5-6):223-231.

Jurišić M, Hengl T, Stanisavljević S (2005). Prostorno planiranje poljoprivredne proizvodnje - Vinogradarstvo: metodološki vodić i GIS za odabir novih lokacija za sadnju vinograda. Studija za potrebe Osječko baranjske županije. Osijek.

Martinović J, Vranković A (1997). Baza tala Republike Hrvatske. I-III. Ministarstvo zaštite okoliša i prostornog planiranja, Zagreb. p. 365.

NASA (2005a). Moderate Resolution Imaging Spectroradiometer (MODIS) imagery. http://edcimswww.cr.usgs.gov/pub/imswelcome/

Olaya V (2004). A Gentle Introduction to SAGA GIS. http://sourceforge.net/projects/saga-gis/files/.
The 52North (2007). ILWIS software - User guide. http://52north.org/communities/ilwis/download. 